\title{
DAMPAK KEBERADAAN DESTINASI WISATA TERHADAP KEHIDUPAN SOSIAL EKONOMI MASYARAKAT DI DIKECAMATAN SIDAMULIH KABUPATEN PANGANDARAN PROVINSI JAWA BARAT
}

\author{
Oleh \\ Budi Margono \\ Institut Pemerintahan Dalam Negeri \\ margonobudi07@gmail.com
}

\begin{abstract}
$T$ The existence of tourist destinations in the District of Sidamulih in Pangandaran Regency, has a big influence on the socio-economic life of the local community, this is because the District of Sidamulih has several excellent tourism destinations, such as beach tourism destinations, natural tourism destinations and cultural tourism destinations. Communities in Sidamulih Regency, have the ability to act and are empowered in producing the products of the Sidamulih community production, which can be marketed as souvenirs or souvenirs for tourists visiting the Sudamulih District. Pangandaran in general is a tourist destination in the Province of West Java, which grows and develops, becoming a destination that can be prospected to make the existence of tourism destinasi in Pangandaran Regency become a global destination, in Indonesia, after Bali and NTB on Lombok Beach. So that researchers are interested in conducting research in the District of Sidamulih, with the title Impact of the Existence of Tourist Destinations on the Socio-Economic Life of Communities in Sidamulih District in Pangandaran Regency, this study uses descriptive qualitative methods, and theories related to the problem of tourist destinations, conclusions that can be obtained are, a positive influence, with the existence of a tourist destination in Kecamatan Sidamulih, on the Socio-Economic Community in the District of Sidamulih in Pangandaran Regency.
\end{abstract}

Keywords: impact, tourism destinations, community's social economy.

\begin{abstract}
AbSTraK
$\mathrm{K}^{\mathrm{s}}$ eberadaan destinasi wisata di Kecamatan Sidamulih di Kabupaten Pangandaran, membawa pengaruh besar terhadap kehidupan social ekonomi masyarakat setempat, hal ini dikarenakan Kecamatan Sidamulih memiliki beberapa destinasi wisata yang dapat diunggulkan, seperti destinasi wisata pantai, destinasi wisata alam dan destinasi wisata budaya. Masyarakat di Kabupaten Sidamulih, memiliki kemampuan untuk berbuat dan berdaya di dalam memproduksi hasil produksi lokasl masyarakat Sidamulih, yang dapat dipasarkan sebagai cenderamata atau oleh-oleh bagi para wisatawan yang berkunjung di Kecamatan Sudamulih. Pangandaran secara umum merupakan destinasi wisata di Provinsi di Jawa Barat, yang tumbuh dan berkembang, menjadi destinasi yang dapat diprosikan untuk menjadikan keberadaan destinasi wisata di Kabupaten Pangandaran menjadi destinasi kelasa dunia, di Indonesia, setelah Pulau Bali dan Pulau NTB di Pantai Lombok. Sehingga peneliti tertarik untuk melakukan penelitian di Kecamatan Sidamulih, dengan Judul Dampak Keberadaan Destinasi
\end{abstract}


Wisata Terhadap Kehidupan Sosial Ekonomi Masyarakat di Kecamatan Sidamulih di Kabupaten Pangandaran, penelitian ini menggunakan metode deskriptif kualitatif, dan teori-teori terkait dengan permasalahan destinasi wisata, simpulan yang dapat diperoleh adalah, adanya pengaruh positif, dengan keberadaan destinasi wisata di Kecamatan Sidamulih, terhadap Sosial Ekonomi Masyarakat di Kecamatan Sidamulih di Kabupaten Pangandaran.

Kata kunci : dampak, destinasi wisata, sosial ekonomi masyarakat

\section{PENDAHULUAN}

$\mathrm{D}$

estinasi wisata di Indonesia, saat ini semakin berkembang, di mana banyaknya destinasi di Indonesia, saat ini menjadi destinasi wisata yang dapat diandalkan, dan memiliki daya Tarik wisata yang dapat mendukung penerimaan Negara. Beberapa destinasi wisata, seperti destinasi pulau Bali, yang merupakan tujuan wisatawan mancanegara, dari dahulu, dan saat ini destinasi di Nusa Tenggara Barat, di Lombok, dan Destinasi Wisata di Kabupaten Pangandaran, serta beberapa destinasi di daerah lain di Indonesia, Ke depan Destinasi wisata dapat dijadikan sumber penerimaan Negara dan daerah yang sangat potensial, sehingga perlu diambil kebijakan-kebijakan yang serius untuk dapat mengembangkan dan menggali potensi ini. Perkembangan pariwisata internasional pada umumnya didorong oleh muncul pembelian paket wisata yang berkesinambungan dari tujuan wisata satu ke tujuan wisata berikutnya, dan ini sudah merupakan ciri-ciri masyarakat wisata mancanegara saat ini.

Tak ketinggalan juga negara kita dengan melihat wisata alamnya yang memiliki potensi untuk dapat dikembangkan. Hampir di seluruh wilayah Indonesia memiliki keindahan alam yang cukup baik untuk dapat dijadikan daerah tujuan wisata. Seperti yang kita tahu Indonesia merupakan negara kepulauan terbesar di dunia yang memiliki kombinasi iklim tropis dengan 17.508 pulau dan di antaranya 6.000 pulau tidak dihuni.
Keindahan alam yang tersebar hampir di seluruh penjuru Indonesia ini membuat setiap daerah di Indonesia memiliki daerah tujuan wisatanya masing-masing. Tak heran pada 2009 Indonesia kedatangan tujuh juta lebih wisatawan dengan pemasukan terbesar ketiga perekonomian negara (sumber :www.bps.go.id, 2012). Pesona itu mampu membuat turis-turis penasaran dan ingin menjelajahi Nusantara. Jumlah wisatawan mancanegara (wisman) yang berkunjung ke Indonesia akhir tahun 2013, jumlahnya mencapai 8,6 juta orang. Ini adalah rekor kunjungan wisman ke Indonesia. Jumlah ini mengalami pertumbuhan $7,37 \%$ dibanding tahun 2012 dengan jumlah 8,04 juta orang. "Tahun ini sepertinya tahun okey untuk pariwisata atau ekonomi kreatif," ujar Menparekraf, Mari Elka Pangestu dalam Jumpa Pers Akhir Tahun 2013 di Balairung Soesilo Soedarman, Gedung Sapta Pesona, Jl Medan Merdeka Barat, Jakarta (Detik Travel).

Pangandaran adalah salah satu kabupaten yang ada di Provinsi Jawa Barat. Kabupaten Pangandaran merupakan salah satu tempat wisata pantai yang terkenal yang ada di Jawa Barat. Daya tarik wisata pantai Pangandaran tidak hanya dikenal oleh wisatawan domestik tetapi juga dikenal oleh wisatawan mancanegara. sebagai daerah tujuan wisata, Pangandaran menempatkan sektor pariwisata sebagai sektor andalan. Pariwisata telah menjadi salah satu industri yang mampu memberikan dampak yang besar terhadap perekonomian di Kabupaten Pangandaran. Pangandaran adalah salah satu tempat wisata yang tidak hanya terkenal dengan keindahan pantainya tetapi terkenal juga dengan banyak objek wisata 
lainnya seperti di Kecamatan Sidamulih. Kecamatan Sidamulih adalah sebuah wilayah di Kabupaten di Pangandaran memiliki beberapa destinasi wisata seperti wisata pantai, wisata budaya dan wisata alam yang sangat spesifik sekali, masyarakat di Kecamatan Sidamulih sangat mendukung dengan keberadaan destinasi wisata di Kabupaten Pangandaran, khususnya di Kecamatan Sidamulih,

\section{Identifikasi masalah}

Melihatsemuahalyangmelatarbelakangi kebudayaan pariwisata maka, kami menarik beberapa masalah dengan berdasarkan kepada Kecamatan sidamulih sebagai kawasan yang mempunyai banyak potensi wisata seharusnya dapat dimanfaatkan masyarakat setempat dalam bidang ekonomi maupun sosial. Sehingga pariwisata di Kecamatan Sidamulih dapat meningkatkan kondisi ekonomi maupun sosial masyarakat.

\section{Rumusan Masalah}

Dengan keterbatasan waktu yang peneliti miliki, peneliti mencoba merumuskan masalah penelitian adalah : Bagaimana Dampak dan pengaruh Pariwisata di Kecamatan Sidomulih , terhadap kondisi Sosial Ekonomi Masyarakat.

\section{Tujuan Penelitian}

Untuk mendeskripsikan dan menganalisis Dampak dan pengaruh Pariwisata di Kecamatan Sidomulih, terhadap kondisi Sosial Ekonomi Masyarakat

\section{TINJAUAN PUSTAKA}

\section{Dampak Pariwisata}

Pariwisata dianggap sebagai salah satu sektor ekonomi penting tetapi apabila tidak dilakukan dengan benar, maka pariwisata berpotensi menimbulkan masalah atau dampak negatif terhadap kehidupan sosial, ekonomi, dan lingkungan Suwantoro,
(1997). Yoeti, (2008) mengemukakan bahwa pariwisata sebagai katalisator dalam pembangunan karena dampak yang diberikannya terhadap kehidupan perekonomian di negara yang dikunjungi wisatawan.

Clement dikutip Yoeti (2008) mengatakan dampak pariwisata idealnya dilihat melalui pendekatan komprehesif. Ada keterkaitanhubungantimbalbalikyangsaling memengaruhi antara dampak lingkungan, ekonomi, dan sosial. Ketimpangan pada salah satu aspek akan berpengaruh pada aspek lainnya. Oleh karenanya, tantangan pembangunan pariwisata terletak pada kemampuan untuk memfasilitasi semua kepentingan lingkungan, ekonomi, dan sosial dalam proporsi yang seimbang dan saling menunjang.

Menurut Retnowati (2004), adanya aktivitas ekowisata (pariwisata) dapat memberi manfaat kepada masyarakat setempat dengan pembukaan lapangan kerja, kesempatan berusaha, dan pendanaan yang diserap kembali dalam bentuk proyekproyek pembangunan daerah.

Yoeti (2008) mengungkapkan bahwa berdasarkan kacamata ekonomi makro, pariwisata memberikan dampak positif yaitu: (i) dapat menciptakan kesempatan berusaha; (ii) dapat meningkatkan kesempatan kerja (employment); (iii) Dapat meningkatkan pendapatan sekaligus mempercepat pemerataan pendapatan masyarakat; (iv) dapat meningkatkan penerimaan pajak pemerintah dan retribusi daerah; (v) dapat meningkatkan pendapatan nasional atau Gross Domestic Bruto (GDB); (vi) dapat mendorong peningkatan investasi dari sektor industri pariwisata dan sektor ekonomi lainnya; (vii) dapat memperkuat neraca pembayaran. Dalam melihat dampak sosial budaya pariwisata terhadap masyarakat setempat, Pitana dan Gayatri (2004) menyatakan bahwa masyarakat tidak dapat dipandang sebagai sesuatu yang 
internally totally integrated entity, melainkan harus juga dilihat segmen-segmen yang ada atau melihat interest groups.

Hal tersebut disebabkan dampak terhadap kelompok sosial yang satu belum tentu sama bahkan bisa bertolak belakang dengan dampak terhadap kelompok sosial yang lain.

Dampak pariwisata terhadap kehidupan sosial budaya masyarakat setempat sangat sulit diukur dan umumnya dipandang oleh masyarakat setempat hanya memberikan dampak negatif. Dampak positif sosial budaya dari aktivitas pariwisata adalah terjadinya pemahaman dan saling pengertian antarbudaya (intercultural understanding) antara pengunjung wisata dengan masyarakat setempat, di mana pengunjung (turis) mengenal dan menghargai kehidupan sosial budaya masyarakat setempat dan sebaliknya masyarakat setempat juga dapat memahami dan menghargai latar belakang sosial budaya turis. Masyarakat terkadang memandang turis sebagai orang yang lebih kaya dan lebih baik secara sosial dengan gaya hidup yang menyenangkan sehingga mereka berusaha meniru gaya hidup turis yang mereka lihat.

Wood (1994) dikutip Pitana dan Gayatri (2004) mengemukakan bahwa di dalam melihat pengaruh pariwisata terhadap masyarakat (dan kebudayaan) harus disadari bahwa kebudayaan adalah sesuatu yang secara internal terdeferensiasi, aktif, dan selalu berubah. Oleh karena itu, pendekatan yang kiranya baikadalah dengan menganggap bahwa pariwisata adalah "pengaruh dari luar yang kemudian terintegrasi dengan masyarakat" di mana masyarakat mengalami proses menjadikan pariwisata sebagai bagian dari kebudayaannya.

\section{Pariwisata}

Pengertian pariwisata menurut A.J Burkat dalam Damanik (2006),pariwisata adalah perpindahan orang untuk sementara dan dalam jangka waktu pendek ke tujuan- tujuan di luar tempat di mana mereka biasa hidup dan bekerja dan juga kegiatankegiatan mereka selama tinggal di suatu tempat tujuan.

Menurut Mathieson \& Wall dalam Pitana dan Gyatri (2005), bahwa pariwisata adalah kegiatan perpindahan orang untuk sementara waktu ke destinasi di luar tempat tinggal dan tempat bekerjanya dan melaksanakan kegiatan selama di destinasi dan juga penyiapan-penyiapan fasilitas untuk memenuhi kebutuhan mereka.

Menurut pendapat yang dikemukakan oleh Yoeti, (1991:103). Pariwisata berasal dari dua kata yaitu Pari dan Wisata. Pari dapat diartikan sebagai banyak, berkalikali,berputar-putar atau lengkap. Sedangkan Wisata dapat diartikan sebagai perjalanan atau bepergian yang dalam hal ini sinonim dengan kata "travel" dalam bahasa Inggris. Atas dasar itu maka kata "pariwisata" dapat juga diartikan sebagai perjalanan yang dilakukan berkali-kali atau berputar-putar dari suatu tempat ke tempat yang lain yang dalam bahasa Inggris disebut juga dengan istilah "Tour"

Sedangkan berdasarkan Undang-Undang No 10 Tahun 2009 tentang kepariwisataan, bahwa keadaan alam, flora, dan fauna sebagai karunia Tuhan Yang Maha Esa, serta peninggalan sejarah, seni, dan juga budaya yang dimiliki bangsa Indonesia merupakan sumber daya dan modal pembangunan kepariwisataan untuk peningkatan kemakmuran dan kesejahteraan rakyat sebagaimana terkandung dalam Pancasila dan Pembukaan Undang-Undang Dasar Negara Republik Indonesia Tahun 1945.

sebagai antisipasi perkembangan dunia pariwisata yang telah mengglobal sifatnya, pemerintah Indonesia mengeluarkan Undang-Undang No. 10 Tahun 2009 tentang kepariwisataan yang terdiri atas tujuh belas bab dan tujuh puluh pasal yang mengandung ketentuan meliputi hal- hal berikut ini. 
1. Wisata adalah kegiatan perjalanan yang dilakukan oleh seseorang atau sekelompok orang dengan mengunjungi tempat tertentu untuk tujuan rekreasi, pengembangan pribadi atau mempelajari keunikan daya tarik wisata yang dikunjungi dalam jangka waktu sementara.

2. Wisatawan adalah orang yang melakukan wisata.

3. Pariwisata adalah berbagai macam kegiatan wisata dan didukung berbagai fasilitas serta layanan yang disediakan oleh masyarakat, pengusaha, pemerintah dan pemerintah daerah.

4. Kepariwisataan adalah keseluruhan kegiatan yang terkait dengan pariwisata dan bersifat multidimensi serta multidisiplin yang muncul sebagai wujud kebutuhan setiap orang dan negara serta interaksi antara wisatawan, pemerintah, pemerintah daerah dan pengusaha.

5. Daya tarik wisata adalah segala sesuatu yang memiliki keunikan, keindahan, dan nilai yang berupa keanekaragaman kekayaan alam, budaya, dan hasil buatan manusia yang menjadi sasaran atau tujuan kunjungan wisatawan.

6. Daerah tujuan pariwisata yang selanjutnya disebut destinasi pariwisata adalah kawasan geografis yang berada dalam satu atau lebih wilayah administratif yang di dalamnya terdapat daya tarik wisata, fasilitas umum, fasilitas pariwisata, aksesibilitas, serta masyarakat yang saling terkait dan melengkapiterwujudnyakepariwisataan.

Berdasarkan definisi pariwisata di atas maka disimpulkan bahwa kegiatan pariwisata mempunyai ciri-ciri sebagai berikut.

1. sebagai daerah tujuan pasti memiliki objek dan juga daya tarik wisata.

2. sebagai daerah tujuan pasti memiliki sarana dan prasarana pariwisata.
3. Pelaksana perjalanan ke daerah tujuan dilakukan dalam waktu sementara.

4. Terdapat dampak yang ditimbulkan,khususnya daerah tujuan segi sosial budaya, ekonomi dan lingkungan.

\section{Proses Sosial (Kerja Sama)}

Soekanto (1990) mengungkapkan bahwa interaksi sosial adalah hubungan-hubungan sosial yang dinamis yang menyangkut hubungan-hubungan sosial yang dinamis antara orang-orang perorangan, antara kelompok-kelompok manusia, maupun antara orang perorangan dengan kelompok manusia. Suatu interaksi sosial tidak akan mungkin terjadi apabila tidak memenuhi dua syarat, yaitu adanya kontak sosial dan komunikasi. Kata kontak berasal dari bahasa latin con atau cum (yang artinya bersamasama) dan tango (yang artinya menyentuh), jadi artinya secara harafiah adalah bersamasama menyentuh. Secara fisik kontak baru terjadi apabila terjadi hubungan badaniah, sebagai gejala sosial itu tidak perlu berarti suatu hubungan badaniah karena orang dapat mengadakan hubungan dengan pihak lain tanpa menyentuhnya. Komunikasi adalah seseorang memberikan tafsiran pada perilaku orang lain (yang berwujud pembicaraan, gerak-gerak badaniah atau sikap), perasaan-perasaan apa yang ingin disampaikan oleh orang tersebut. Bentukbentuk interaksi sosial dapat berupa kerja sama (cooperation), persaingan (competition), dan bahkan dapat juga berbentuk pertentangan atau pertikaian (conflict).

\section{Kajian Legalistik}

Pendekatan legalistik adalah salah satu cara untuk melihat gejala dan peristiwa dari sudut pandang aturan-aturan formal. Hal tersebut sekaligus menjadi ciri yang membedakan ilmu pemerintahan dan ilmu-ilmu sosial lainnya. Kajian-kajian 
pemerintahan tidak dapat dilepaskan dari peraturan perundang-undangan sebagai hukum positif yang mengatur berjalannya pemerintahan.

Termasuk dalam penelitian ini, pendekatan legalistik yang digunakan dalam penelitian ini mencakup:

- Undang-Undang Nomor 21 Tahun 2012 tentang Pembentukan Kabupaten Pangandaran di Provinsi Jawa Barat

Kabupaten Ciamis adalah kabupaten sebagaimana dimaksud dalam UndangUndang Nomor 14 Tahun 1950 tentang Pemerintahan Daerah Kabupaten dalam Lingkungan Jawa Barat yang wilayahnya telah dikurangi dengan Kota Banjar berdasarkan Undang-Undang Nomor 27 Tahun 2002 tentang Pembentukan Kota Banjar di Provinsi Jawa Barat, yang merupakan kabupaten asal Kabupaten Pangandaran.

- Peraturan Daerah Nomor 14 Tahun 2015 tentang Penyelenggaraan Kepariwisataan Kabupaten Pangandaran

Dalam peraturan daerah ini dimuat peraturan yang mengatur tentang pelaksanaan pariwisata di Kabupaten Pangandaran. Disebutkan dalam ketentuan umum Perda Nomor 14 Tahun 2015 tentang Penyelenggaraan Kepariwisataan Kabupaten Pangandaran.

Pariwisata adalah berbagai macam kegiatan wisata dan didukung berbagai fasilitas serta layanan yang disediakan oleh masyarakat, pengusaha, Pemerintah dan Pemerintah Daerah.

Dapat diambil simpulan bahwa pariwisata di Kabupaten Pangandaran bukan hanya disediakan dan bukan hanya tanggung jawab dari pemerintah saja. Dalam kegiatan pariwisata di Kabupaten Pangandaran tetap mengikutsertakan masyarakat dalam usaha peningkatannya.
Kepariwisataan adalah keseluruhan kegiatan yang terkait dengan pariwisata dan bersifat multidimensi serta multidisiplin yang muncul sebagai wujud kebutuhan setiap orang dan negara serta interaksi antara wisatawan dan masyarakat setempat, sesama wisatawan, pemerintah, pemerintah daerah dan pengusaha.

Begitu juga partisipasi masyarakat dalam usaha peningkatan pariwisata di Kabupaten Pangandaran. Dalam bab XII tentang peran serta masyarakat Pasal 45 disebutkan sebagai berikut.

(1) Masyarakat berperan serta dalam kegiatan kepariwisataan melalui:

- peningkatan Sadar Wisata;

- partisipasi aktif dalam pengembangan kepariwisataan;

- menyampaikan saran, pendapat dan aspirasi dalam rangka pengembangan kepariwisataan;

- penggalian potensi dan sumber daya ekonomi, kewirausahaan, sosial, seni dan budaya, teknologi untuk mendukung kepariwisataan;

- pembentukan organisasi, asosiasi industri dan profesi serta lembaga kemasyarakatan lain untuk mendukung pengembangan kepariwisataan; dan

- penyelenggaraan pendidikan dan pelatihan kepariwisataan.

(2) Peran serta masyarakat sebagaimana dimaksud pada ayat (1) harus didorong oleh Pemerintah Daerah.

\section{Visi dan misi Kabupaten Pangandaran}

Kabupaten Pangandaran saat ini sedang gencar-gencarnya untuk meningkatkan kualitas wisatanya. Bukan hanya wisata alam namun juga wisata buatannya sesuai dengan visi Kabupaten Pangandaran yaitu "Kabupaten Pangandaran sebagai Tujuan Wisata Berkelas Dunia” 
Adapun misi Kabupaten Pangandaran sebagai berikut.

1. Mewujudkan tata kelola pemerintahan yang akuntabel, bersih dan melayani

2. Mewujudkan penataan ruang yang harmonis dan pengendalian pemanfaatan ruang yang berwawasan lingkungan

3. Menyediakan infrastruktur dan fasilitas yang berkualitas

4. Memperkuat ketahanan nilai-nilai kearifan lokal.

5. Membangun sumber daya manusia yang mandiri, berkualitas dan berdaya saing.

6. Membangun perekonomian yang tangguh, maju, berkeadilan dan berkelanjutan.

Sesuai dengan Visi dan Misi Bupati terpilih sektor Pariwisata di Kabupaten Pangandaran merupakan salah satu tujuan utama destinasi wisata di Indonesia, hal ini termaktub dalam PP No. 50 Tahun 2011 RIPPARNAS 2010 - 2025 yang menetapkan Kabupaten Pangandaran sebagai salah satu Kawasan Strategis Pariwisata Nasional (KSPN).

\section{METODE PENELITIAN}

Penelitian adalah sebuah proses kegiatan mencari kebenaran terhadap suatu fenomena ataupun fakta yang terjadi dengan cara yang terstruktur dan sistematis. Dalam sebuah penelitian diperlukan metode penelitian yang akan digunakan pada saat melaksanakan penelitian. Metode penelitian adalah tata cara bagaimana suatu penelitian dilaksanakan (Hasan, 2002: 21). Pengertian lain dari metode penelitian ialah cara yang digunakan oleh peneliti dalam mengumpulkan data penelitiannya, seperti wawancara, observasi, tes maupun dokumentasi (Arikunto, 2002: 136). sedangkan menurut Subagyo (2006: 2) metode penelitian merupakan suatu cara atau jalan untuk memperoleh kembali pemecahan terhadap segala permasalahan. Pada penelitian ini penulis menggunakan metode penelitian kualitatif. Penelitian kualitatif adalah metode penelitian yang berfokus pada pemahaman terhadap fenomena sosial yang terjadi di masyarakat.

Menurut Creswell, penelitian kualitatif adalah proses untuk memahami masalah sosial berdasarkan metodologi yang berbeda. Dalam hal ini, peneliti akan menyusun gambaran yang kompleks, menganalisis kata demi kata dan menyusun hasil penelitian secara natural/sesuai fakta di lapangan.

Adapun data yang dikumpulkan bersumber dari data primer dan data sekunder. Data primer adalah sumber data penelitian yang diperoleh secara langsung dari sumber aslinya yang berupa wawancara, jajak pendapat dari individu atau kelompok (orang) maupun hasil observasi dari suatu objek, kejadian atau hasil pengujian (benda). Menurut Hasan (2002:82), data primer ialah data yang diperoleh atau dikumpulkan langsung di lapangan oleh orang yang melakukan penelitian atau yang bersangkutan yang memerlukannya.

Sedangkan data sekunder adalah sumber data penelitian yang diperoleh melalui media perantara atau secara tidak langsung yang berupa buku, catatan, bukti yang telah ada, atau arsip baik yang dipublikasikan maupun yang tidak dipublikasikan secara umum. Data sekunder adalah data yang diperoleh atau dikumpulkan oleh orang yang melakukan penelitian dari sumber-sumber yang telah ada (Hasan, 2002:58). Dengan kata lain, peneliti membutuhkan pengumpulan data dengan cara berkunjung ke perpustakaan, pusat kajian, pusat arsip atau membaca banyak buku yang berhubungan dengan penelitiannya.

\section{Teknik Pengumpulan Data}

Dalam kesempatan penelitian ini dilakukan pendekatan secara analisis kualitatif melalui, analisis kualitatif 
mengandung mana suatu penggambaran atas data dengan menggunakan kata dan baris kalimat. Penelitian juga lebih menekankan pada objektivitas dan kejujuran yang diwujudkan dengan menjelaskan tujuan penelitian kepada informan. Data dan informasi yang digunakan dalam penelitian ini didapat dari wawancara dan disesuaikan dengan data milik Kecamatan Sidamulih.

Penelitian ini menggunakan metode penelitian kualitatif deskriptif. Penelitian deskriptif berusaha menggambarkan suatu gejala sosial. Penelitian ini lebih memfokuskan pada studi kasus yang merupakan penelitian yang rinci mengenai suatu objek tertentu selama kurun waktu tertentu.

\section{Teknik Analisis Data}

Teknik analisis data yang digunakan adalah analis secara induktif, dengan model metode perbandingan tetap. Metode ini dimulai dengan reduksi data, pengkategorisasian, sintesisasi dan penyusun hipotesis kerja.

Untuk menganalisis penelitian ini maka dilakukan dengan langkah-langkah sebagai berikut.

- Pengumpulan informasi, melalui wawancara dan internet.

- Reduksi.

Langkah ini adalah untuk memilih informasi mana yang sesuai tidak sesuai dengan masalah penelitian.

- Penyajian.

Setelah informasi dipilih maka disajikan dalam bentuk tabel ataupun uraian kejelasan.

- Menarik kesimpulan

\section{HASIL DAN PEMBAHASAN}

sebagai daerah otonom baru, Kabupaten Pangandaran, memiliki destinasi wisata yang sangat potensial, dan sangat strategis sekali, sehingga untuk mencapai Pangandaran sebagai destinasi kelas Dunia, Pemerintah Kabupaten Pangandaran memiliki Visi dan Misi sebagai berikut.

\section{Visi dan misi Kabupaten Pangandaran}

Kabupaten Pangandaran saat ini sedang gencar-gencarnya untuk meningkatkan kualitas wisatanya. Bukan hanya wisata alam namun juga wisata buatannya sesuai dengan visi Kabupaten Pangandaran yaitu "Kabupaten Pangandaran sebagai Tujuan Wisata Berkelas Dunia"

Adapun misi Kabupaten Pangandaran sebagai berikut.

1. Mewujudkan tata kelola pemerintahan yang akuntabel, bersih dan melayani

2. Mewujudkan penataan ruang yang harmonis dan pengendalian pemanfaatan ruang yang berwawasan lingkungan

3. Menyediakan infrastruktur dan fasilitas yang berkualitas

4. Memperkuat ketahanan nilai-nilai kearifan lokal.

5. Membangun sumber daya manusia yang mandiri, berkualitas dan berdaya saing

6. Membangun perekonomian yang tangguh, maju, berkeadilan dan berkelanjutan

Sesuai dengan Visi dan Misi Bupati terpilih sektor Pariwisata di Kabupaten Pangandaran merupakan salah satu tujuan utama destinasi wisata di Indonesia, hal ini termaktub dalam PP No. 50 Tahun 2011 RIPPARNAS 2010 - 2025 yang menetapkan Kabupaten Pangandaran sebagai salah satu Kawasan Strategis Pariwisata Nasional (KSPN).

sebagai daerah tujuan wisata Kabupaten Pangandaran, melakukan beberapa kebijakan yang mendukung agar destinasi wisata Pangandaran sebagai tujuan wisata kelas dunia. Yang dilakukan beberapa tahun terakhir adalah dengan melakukan peyempurnaan sarana dan 
prasarana fisik, baik jalan-jalan lingkungan di wilayah Kabupaten Pangandaran, Akomodasi untuk para pengunjung wisata, yang memiliki standar internasional, dan nasional berkelas, yang dapat dinikmati oleh para wisatawan mancanegara dan wisatawan local dalam negeri. Satu yang masih belum dapat diwujudkan, bagaimana menjadikan lapangan terbang yang ada saat ini, dapat dikembangkan dan dijadikan lapangan terbang internasional, yang dapat diakses lebih mudah oleh para wisatawan mancanegara dan wisatawan local. Kondisi ini yang harus disegerakan oleh Pemerintah dan Pemerintah Daerah.

\section{Potensi Pariwisata yang ada di Kecamatan Sidamulih}

Kecamatan Sidamulih merupakan kecamatan yang ada di Kabupaten Pangandaran Provinsi Jawa Barat. Kecamatan Sidamulih memiliki luas wilayah 77,98 kilometer persegi, jumlah penduduk 30125 jiwa. Kecamatan Sidamulih terdiri atas tujuh desa, yaitu Cikalong, Cikembulan, Kalijati, Kersaratu, Pejaten, Sidamulih, dan Sukaresik.

Kecamatan Sidamulih merupakan kecamatan yang berpotensi dalam bidang pariwisata. Jenis pariwisata di Kecamatan Sidamulih dibagi menjadi tiga jenis:

\section{- Ekonomi}

Wisatawan menjadi konsumen dari UMKM Kecamatan Sidamulih. Beberapa UMKM di Kecamatan Sidamulih:

\section{- Industri tempe di Desa Cikembulan}

Kabupaten Pangandaran memiliki potensi besar dalam pengembangan sektor agroindustri, hal tersebut dikarenakan Kabupaten Pangandaran merupakan Kabupaten yang mayoritas penduduknya berprofesi sebagai petani. Salah satu agroindustri yang cukup menjanjikan untuk dikembangkan di Kabupaten Pangandaran adalah agroindustri tempe yang berbahan dasar kedelai yang diproduksi di Kecamatan Sidamulih Kabupaten Pangandaran.

Dari hasil penelitian didapatkan hasil berupa besarnya biaya yang dikeluarkan (biaya tetap dan biaya variabel) dari agroindustri tempe dalam satu kali proses produksi di Desa Cikembulan Kecamatan SidamulihKabupaten Pangandaran adalah sebesar Rp2.365.726,37. Hasil produksi tempe dalam satu kali proses produksi di Desa Cikembulan Kecamatan Sidamulih Kabupaten Pangandaran adalah sebanyak 2.500 bungkus dengan harga pada saat penelitian sebesar Rp 800 dan Rp1.700 per bungkus. Maka penerimaan total sebesar Rp 3.350.000. Sehingga pendapatan yang diperoleh dari agroindustri tempe dalam satu kali proses produksi di Desa Cikembulan Kecamatan Sidamulih Kabupaten Pangandaran adalah sebesar Rp 984.273,63.

\section{- Keripik pisang rumput laut di Desa} Pejaten

Masyarakat desa Pejaten berinovasi dalam mengkreasikan produk yang berbahan dasar buah pisang, salah satunya adalah keripik pisang dengan bumbu rumput laut. Sehingga produk yang dihasilkan dapat menjadi produk andalan dan khas di Kabupaten Pangandaran.

\section{- Biji kopi robusta di Desa Kersaratu}

Kecamatan Sidamulih merupakan Kecamatan yang memiliki areal produksi biji kopi yang luasnya ke tiga dibanding dengan kecamatan lainnya, di Kabupaten Pangandaran luas lahan 423,48 hektar, produksi biji kopi yang dihasilkan di Kabupaten Pangandaran sebanyak $20.514,21$ ton, produktivitas dengan ratarata 43.827,12 kilogram per hektar. Luas lahan yang ditanami kopi oleh petani kurang lebih 46,78 hektar dan daerah Kecamatan Sidamulih merupakan daerah yang luas areal yang ditanami kopi, ke tiga dibanding dengan kecamatan Langkap lancar yang memiliki Luas149,72 hektar 
dan Kecamatan Parigi memiliki luas lahan 70,45 hektar, untuk Kecamatan Kalipucang, Padaherang, Cigugur, Cijulang, Pangandaran, Cimerak dan Mangunjaya memiliki luas lahan $<60$ hektar.

Desa Kersaratu merupakan Desa yang termasuk di Kecamatan Sidamulih Kabupaten Pangandaran dan merupakan salah satu daerah penghasil kopi yang berjenis robusta di wilayah Kabupaten Pangandaran Provinsi Jawa Barat dan desa Kersaratu memiliki luas lahan paling luas dibandingkan Desa yang lain, yaitu 23,44 hektar lahan yang sudah menghasilkan dengan jumlah produksi 20,238 ton Produktivitas adalah 43.261,08 kilogram per hektar. Produksi kopi robusta yang berasal dari Desa Kersaratu Kecamatan Sidamulih Kabupaten Pangandaran, sudah dijual ke beberapa daerah di Kabupaten Ciamis, Tasikmalaya, Bandung dan Cirebon, kopi tersebut sudah tersebar di wilayah Provinsi Jawa Tengah seperti Cilacap, Pekalongan dan Purwokerto.

\section{- Gula kelapa di Desa Sukaresik}

Berkembangnya industri rumah tangga pembuat gula kelapa tersebut, telah memberikan nilai positif bagi warga yang tinggal di wilayah tersebut. Tidak hanya sekadar mampu menyerap banyak tenaga kerja, akan tetapi juga meningkatkan kesejahteraan perajin kelapa atau gula merah. Saat ini harga gula kelapa $\mathrm{Rp} 7.800$ per kilogram. Harga tersebut lebih murah dibandingkan sebelumnya yang mencapai Rp 8.000 per kilogram. harga tertinggi gula kelapa yang dialaminya mencapai Rp 12.000 per kilorgam, sedangkan paling rendah Rp 7.000.

\section{- Wisata Alam}

- Wisatawan mengunjungi atraksi alam di Kecamatan Sidamulih.

Kecamatan Sidamulih memiliki potensi wisata alam yang beragam di antaranya:
- Laguna pantai di Desa Sukaresik

- Gua alam di Desa Sidamulih

- Sodong Panjang di Desa Cikalong

- Situ Cirangkong di Desa Cikalong

- Kalijati Hills di Desa Kalijati

\section{- Kebudayaan}

- Wisatawan menghadiri pagelaran kesenian dan pameran kebudayaan di Kecamatan Sidamulih.

Festival kebudayaan yang digelar di Kecamatan Sidamulih:

a. Tradisi Ngabuku Taun di Desa Cikalong

Sudah menjadi tradisi dan turun temurun masyarakat di Desa Cikalong, Kecamatan Sidamulih, Kabupaten Pangandaran menggelar prosesi ngabuku taun atau pesta tabungan dari lumbung padi dari hasil bumi yang mereka garap selama satu tahun. ngabuku taun ini rutin dilakukan setahun sekali setiap memperingati 1 Muharam di mana seluruh warga di Desa Cikalong serempak tidak melakukan aktivitasnya di ladang pertanian alias libur.

b. Tradisi Ngabuku Taun di Desa Cikalong yang dilaksanakan tiap Muharam ini merupakan salah satu kebudayaan atau tradisi yang mesti dilestarikan keberadaannya, dan diturunkan ke generasi muda.

c. Seni Ronggeng Gunung di Desa Cikalong Kesenian Ronggeng Gunung merupakan kesenian asli yang berasal dari Kabupaten Pangandaran tepatnya di Desa Cikalong Kecamatan Sidamulih. Kesenian ini sangat erat kaitannya dengan kerajaan Pananjung, hal tersebut disimpulkan berdasarkan cerita yang diperoleh dari masyarakat dan petunjuk dari situs-situs yang berada di daerah Ciamis bagian selatan tersebut. 


\section{d. Seni Ngagondang di Desa Cikalong}

Kesenian gondang merupakan adat masyarakat Desa Cikalong dulu ketika akan menumbuk padi untuk dijadikan tepung sebagai bahan baku pembuatan dodol untuk acara hajatan.

e. Ritual Babarit di Desa Cikalong, Desa Sidamulih, dan Desa Kersaratu

Tradisi ini rutin digelar pada bulan Dzulkaidah atau bulan Hapit. Tradisi babarit ini pun memiliki filosofi kebersamaan antar warga. Karena apabila acara ritual ini digelar, berarti warga di tiga desa itu tengah mengalami kesulitan. Makanya, pada acara tradisi ini, semua warga membawa makanan dari rumahnya dan kemudian berkumpul untuk saling mencicipi makanan yang mereka bawa.

f. Mitembeyen

Tradisi panen padi pertama kali sebagai wujud syukur petani yang dilakukan rutin oleh masyarakat Sidamulih di masing-masing desa di Kecamatan Sidamulih

\section{Pengaruh pariwisata terhadap ekonomi masyarakat di Kecamatan Sidamulih}

Pengukuran mengenai struktur pendapatan masyarakat pada penelitian ini ditujukan untuk mengetahui sejauh mana kontribusi keberadaan industri pariwisata terhadap jumlah dan tingkat pendapatan masyarakat setempat. Untuk mengukur hal tersebut, dilakukan analisis terhadap struktur pendapatan masyarakat khususnya kepada rumah tangga pelaku usaha pariwisata. Menurut penuturan beberapa responden, kegiatan pariwisata memiliki andil cukup besar dalam menopang pendapatan rumah tangga. Pariwisata menjadi pilihan strategi nafkah yang dapat diandalkan untuk mempertahankan kondisi ekonomi rumah tangga. Pendapatan dari sektor pariwisata pada rumah tangga yang melakukan multi usaha berasal dari beragam sumber, yaitu jenis usaha yang diteliti (ojeg perahu, pedagang kaki lima, tukang becak, rental sepeda) dan jenis usaha lain yang masih di sektor pariwisata. Rumah tangga yang menerapkan jenis usaha tunggal maka seluruh pendapatannya berasal dari sumber nafkah, yaitu pariwisata.

Besarnya pendapatan yang diperoleh dari sektor pariwisata erat kaitannya dengan jumlah kunjungan wisatawan. Oleh karenanya, besar pendapatan yang diterima para pelaku usaha pariwisata selalu mengalami pasang surut sesuai musim kunjungan wisatawan. Umumnya dibedakan menjadi 4 musim, yaitu musim sepi pengunjung seperti hari kerja; musim libur sabtu-Minggu (weekend); musim libur long weekend; dan musim puncak kunjungan wisatawan pada hari-hari besar seperti hari raya, liburan sekolah, dan tahun baru. Pada saat musim liburan atau hari sabtu dan minggu, banyak wisatawan datang berkunjung dan menginap di sana, maka pendapatan masyarakat sebagai pelaku usaha bisa mencapai Rp50.000. sampai Rp1.000.000. bahkan bisa sampai dengan Rp2.000.000. per harinya. Karena Kunjungan wisatawan sangat banyak sekali pada hari long weekend. Tingginya pendapatan yang diperoleh pada saat musim puncak kunjungan wisatawan biasanya digunakan sebagai tabungan untuk mencukupi kebutuhan sehari-hari pada saat musim sepi kunjungan. Ada pula yang menggunakannya sebagai modal untuk membuka usaha baru atau memperluas skala usaha yang sudah ada.

Jumlah pengunjung/wisatawan memengaruhi besarnya permintaan akan pelayanan jasa wisata. Hubungan antara jumlah pengunjung/wisatawan dengan besarnya permintaan pelayanan jasa adalah searah. Jika jumlah pengunjung/wisatawan menurun, maka permintaan akan pelayanan jasa wisata pun rendah. Hal ini berdampak pada rendahnya omset yang diperoleh para pelaku usaha pariwisata yang sangat bergantung dari 
permintaan wisatawan. Salah satu contoh pada jenis usaha ojeg perahu. para penyedia jasa ojek perahu ini penghasilannya akan turun jika jumlah wisatawan sedikit. hal ini karena perahu tidak dapat berjalan jika tidak ada permintaan dari wisatawan.. Sumber:https://www.kompasiana.com/ albanyilfad/5db7fd45d541df35521b10f2/ dampak-pariwisata-terhadap-perekonomian-masyarakat diakses tanggal 5 Juli 2020.

\section{SIMPULAN}

Kecamatan Sidamulih memiliki potensi yang beragam mulai dari potensi usaha (UMKM), potensi alam, hingga potensi budaya yang sampai sekarang masih dilestarikan dan masih menarik wisatawan datang. Diantara potensi ekonomi atau usaha yang dimiliki oleh Kecamatan Sidamulih yaitu budi daya dan pengembangan usaha kopi robusta, produksi keripik pisang rumput laut serta produksi gula kelapa, dan pembuatan tempe. Dapat memberikan dampak ekonomi yang positif bagi masyarakat setempat, baik dari hasil yang didapatkan ataupun membuka lapangan pekerjaan bagi masyarakat yang belum memiliki pekerjaan. Sedangkan potensi wisata alam terdapat gua alam, laguna pantai, air terjun dan potensi alam lainnya. Selain itu juga Kecamatan Sidamulih memiliki budaya yang sampai saat ini masih dilestarikan. Mulai dari budaya yang dilakukan saat setelah musim panen, maupun budaya yang dilakukan turun temurun pada hari tertentu. Potensi yang dimiliki Kecamatan Sidamulih ini benarbenar dioptimalkan untuk pengembangan Kecamatan Sidamulih sehingga dapat meningkatkan pendapatan ekonominya.

Sementara pada pola kerja sama khususnya antar sesama pelaku usaha, keberadaan industri pariwisata mempererat hubungan di antara pelaku usaha. Hal tersebut terlihat dari adanya organisasi atau kelompok pada masing-masing jenis usaha. Masing-masing organisasi/kelompok ini memiliki aturan mengenai pembagian ruang usaha serta pengelolaannya. Hal ini ditujukan untuk menciptakan kerja sama yang baik antar sesama pelaku usaha. Lebih dari itu, kerja sama juga terjadi antara pelaku usaha dengan masyarakat khususnya dalam hal menjaga kawasan wisata. Selain itu dampak sosial yang terjadi yaitu perubahan gaya bahasa yang terjadi akibat sering berkomunikasi dengan wisatawan. Penduduk yang tinggal di daerah yang dekat dengan kawasan wisata lebih sering menggunakan bahasa Indonesia untuk berkomunikasi. Tetapi tetap ketika berkomunikasi dengan sesama penduduk asli kembali menggunakan bahasa daerah.

Dengan adanya covid 19 dan penerapan PSBB di Kabupaten Pangandaran hampir selama tiga bulan lamanya, baru pada 1 Juli 2020, secara bertahap, destinasi wisata dibuka kembali, itu pun hanya diizinkan kunjungan wisatawan hanya dari Provinsi Jawa Barat saja, destinasi wisata mulai menggeliat kembali walaupun belum normal seratus persen, setidaknya masyarakat telah kembali beraktivitas dalam kondisi pandemic covid 19 yang belum selesai dengan PSBB transisi, adaptasi kebiasaan baru di Kabupaten Pangandaran, dengan tetap melaksanakan protokol kesehatan dalam implementasinya.

\section{SARAN}

Ekonomi masyarakat sangat tergantung dengan adanya kunjungan pariwisata di Kecamatan Sidamulih, namun yang perlu diparhatikan adalah, perlu adanya kerja sama yang terkoordinasi dengan baik, antara para wirausaha yang berada di Kecamatan Sidamulih, satu dengan lainnya, dan dengan Pemerintah Daerah, khususnya, Desa dan Kecamatan, agar tidak adanya saling bersaing, tetapi agar dapat tumbuh kerja sama yang saling menguntungkan, sehingga pengaruh destinasi wisata di Kecamatan 
Sidamulih, dapat memberikan nilai positif, bagi pertumbuhan sosial ekonomi masyarakat di Kecamatan Sidamulih, dan memberikan manfaat bagi masyarakat.

\section{DAFTAR PUSTAKA}

Undang-Undang Nomor 21 Tahun 2012 tentang Pembentukan Kabupaten Pangandaran di Provinsi Jawa Barat.

Peraturan Daerah Nomor 14 Tahun 2015 tentang Penyelenggaraan Kepariwisataan Kabupaten Pangandaran.

Visi dan misi Kabupaten Pangandaran.

Dhalyana, Dini. Adiwibowo, Soeryo. 2013. Pengaruh taman wisata alam pangandaran kondisi sosial ekonomi masyarakat.Vol.01,No.03.Dapat diunduh dari https terhadap://journal.ipb. ac.id/index.php/sodality/article/ download/9402/7367 diakses tanggal 5 Juli 2020 https://www.kompasiana.com/albanyilfad/5db7fd45d541df35521b10f2/dampak-pariwisata-terhadap-perekonomian-masyarakat diakses tanggal 5 Juli 2020

https://jurnal.unigal.ac.id/index.php/ ekonologi/article/view/1359 diakses tanggal 5 Juli 2020

https://jurnal.unigal.ac.id/index.php/artefak/ article/view/1064 diakses tanggal 10 Juli 2020 